\title{
ACCESSIBILITY OF MAJOR CENTRAL AND EASTERN EUROPEAN CITIES IN DANUBE CRUISE TOURISM
}

\author{
Márk MISKOLCZI ${ }^{\mathrm{a}}$, Melinda JÁSZBERÉNYI ${ }^{\mathrm{b},}$ András MUNKÁCSYc, \\ Dávid NAGYd
}

\footnotetext{
${ }^{a}$ Corvinus University of Budapest, Institute of Marketing, mark.miskolczi@uni-corvinus.hu

${ }^{\mathrm{b}}$ Corvinus University of Budapest, Institute of Marketing, jaszberenyi@uni-corinus.hu

${ }^{c}$ KTI Institute for Transport Sciences, munkacsy.andras@kti.hu

${ }^{\mathrm{d}}$ University of Pécs, Doctoral Programme in Earth Sciences, david@info-partner.hu
}

Cite this article: Accessibility of major Central and Eastern European cities in Danube cruise tourism. Deturope. 12(3): 133-150.

\begin{abstract}
This article aims to provide an insight into the largely under-researched issue of river cruise tourism on the Danube through an explorative analysis. The focus is on attraction accessibility in the context of the three major cities of pan-European Corridor VII. (Vienna, Budapest, Belgrade), based on the adaptation of the accessibility model by Geurs \& van Wee (2004). Expert and stakeholder interviews have been carried out and analyzed to understand the general problems and suggested solutions of port and attraction accessibility of these cities. Results indicate that accessibility is influenced not only by transport components: rethinking temporal and individual components as well as developing land-use and transport components may be relevant to overcoming key issues like low water level, overtourism, reliability of services, urban traffic congestion and parking problems on roads. Our research results can serve as a source for urban and transport development strategies and summarizes product development proposals of the members of the tourism sector for cruise tourism on the Danube to ensure accessibility.
\end{abstract}

Keywords: components of accessibility, attraction accessibility, Danube cruise tourism, stakeholder interview, urban mobility

\section{INTRODUCTION}

Cruise tourism is a special form of travelling: it is attached to cruise ships, i.e. mixtures of a tourist attraction, a place for accommodation and a means of transport. Danube cruise tourism is one of the emerging segments of leisure tourism, which primarily combines cultural and other alternative service elements (e.g. wine and gastronomy, arts and crafts, etc.) in its offer (Jászberényi \& Miskolczi, 2020). In the high season, the industry can contribute at least $€$ 110.7 million to the regional economy (remarkable destinations of the region: Vienna, Budapest, Belgrade) (Danube International Programme, 2019). The number of cruise tourists has been steadily increasing in the 2010s, and tour operators usually sell out packages for a season even before the previous has been started. However, despite the ever-increasing 
economic performance of the product, it seems to be ignored by tourism (and transport) research. Previous research is mainly focused on maritime cruises (Johnson, 2002; Brida \& Zapata, 2010; Klein, 2011). River cruise tourism is highly overlooked and only some scholars - obviously from countries with large navigable rivers - are active in this field, even though the product can significantly increase the tourism revenue of a destination (Santos et al., 2019).

This article departs, on the one hand, from the experience that onshore mobility of river cruise tourists has a significant impact on the transport system in certain points of the destinations, especially in Budapest, Belgrade and Vienna which are becoming the most popular cities for cruise tourists. On the other hand, it is supposed that accessibility issues related to tourist sites might affect the tourism experience in this destination.

Accessibility has been in the focus of transport and land use research for decades. In spite of this, accessibility of tourism attractions has rarely been studied: some authors focus on how disabled people access attraction sites (e.g. Israeli, 2002, Yau et al., 2004) and others on how the general public can access a tourist attraction (e.g. Israeli \& Mansfeld, 2003; Toth \& David, 2010). This article aims to contribute to the latter topic, discussing accessibility issues in river cruise tourism. For this reason, accessibility is considered as a complex phenomenon including four key components (land-use, transport, temporal, individual) as suggested by Geurs \& van Wee (2004).

Although the research focuses primarily on the ports mentioned above, most of the (urban) mobility related issues of river cruise tourism are general and not country specific. Thus, outcomes are expected to be relevant to researchers, planners and decision-makers in cruise tourism beyond borders, especially in the Danube region.

In the next section of the article, Danube cruise tourism and the role of Vienna, Budapest and Belgrade are introduced in detail, by highlighting main outcomes of previous research and reviewing products of the largest service providers. Theoretical background and the methodology of the primary research are described afterwards. In the remaining parts of the article, the four components of accessibility are interpreted, and issues of attraction accessibility are discussed by the outcomes of this qualitative research, followed by concluding remarks and the collected recommendations. 


\section{DANUBE CRUISE TOURISM}

\section{General introduction}

Danube cruise tourism is introduced here by the review of previous literature and the information published on the official website of service providers, primarily the dominant operators offering travel for the period between 2019 and 2020. The Danube countries include Austria, Slovakia, Hungary, Croatia, Serbia, Romania and Bulgaria, as well as the border regions of Germany and Ukraine (Fig. 1). It should be emphasized that five European capitals are located along the pan-European corridor VII. - Vienna, Bratislava, Budapest, Belgrade and Bucharest (68 kms from the Danube) - making the region particularly popular among Danube cruise tourists. Budapest, Vienna and Belgrade abound in tourism attractions offering authentic experiences, so these cities are becoming a key part of the current product portfolio (Erfurt-Cooper, 2009).

Figure 1 The 3,500-km waterway of Rhine-Main-Danube.

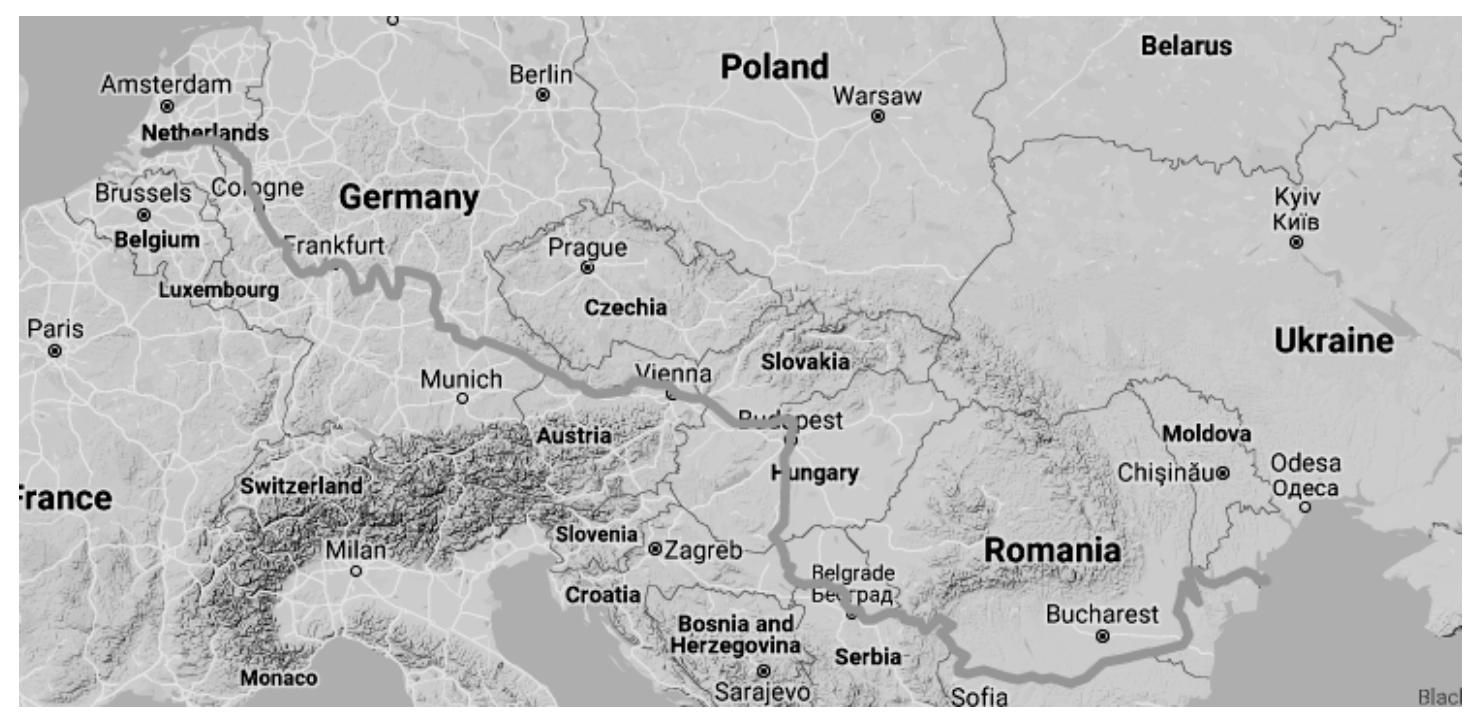

Source: own editing using Google My Maps

Since the opening of the Main Danube Canal in 1992, cruise traffic in the region has been growing steadily. In the 2010s, approximately 150-200 ships ran across the Danube every year. Competition between service providers is strengthening: 10-12 major companies share the market and there are 5 dominant companies (Ásványi, et al., 2018). Cruise ships are characterized by luxury on-board services. River characteristics and bridge heights usually delimitate ship size. An average cruise ship is 120-130 meters long, 11-13 meters wide and has a maximum capacity of 200 people on average (Vuksanović, Pivac \& Dragin, 2013). 
Cruise ships typically include three decks, with an average of 100 suites, rooms with balconies, a lounge, a sun terrace, and a restaurant. All rooms are of a high standard, provide digital equipment and free wireless internet. The product is shaped by seasonality. Typically, there is an 8-9-month active operating period that is followed by a 3-4 months long off-season when special thematic tours are offered (e.g. Christmas fairs along the Danube) (Erdeji \& Dragin, 2017). Cruise tourists would like to visit as many destinations and attractions as possible on a trip, using the least number of means of transport. In the case of cruise tourists, the need for accessible services for people with reduced mobility is significant, as the primary target group is the well-off senior $(60+)$ age group, who are more likely to have musculoskeletal problems and thus reduced physical activity (Jászberényi \& Miskolczi, 2020). American and Western/Northern European (German, Scandinavian, Spanish, English, French) tourists are the main target group of river cruise tourism, and the already emerging role of Chinese tourists is expected to increase in the near future.

\section{The three major ports of the corridor VII.}

The Danube is currently the world's number one destination in the river cruise market, with a share of the world market of approx. 30\% (Danube International Programme, 2019). The cultural-authentic tourist supply of the pan-European cities (Fig. 2) has greatly contributed to this eminent performance (Rácz, 2014).

Figure 2 The 3,500-km waterway of Rhine-Main-Danube: highlighted ports: Vienna (Austria), Budapest (Hungary), Belgrade (Serbia).

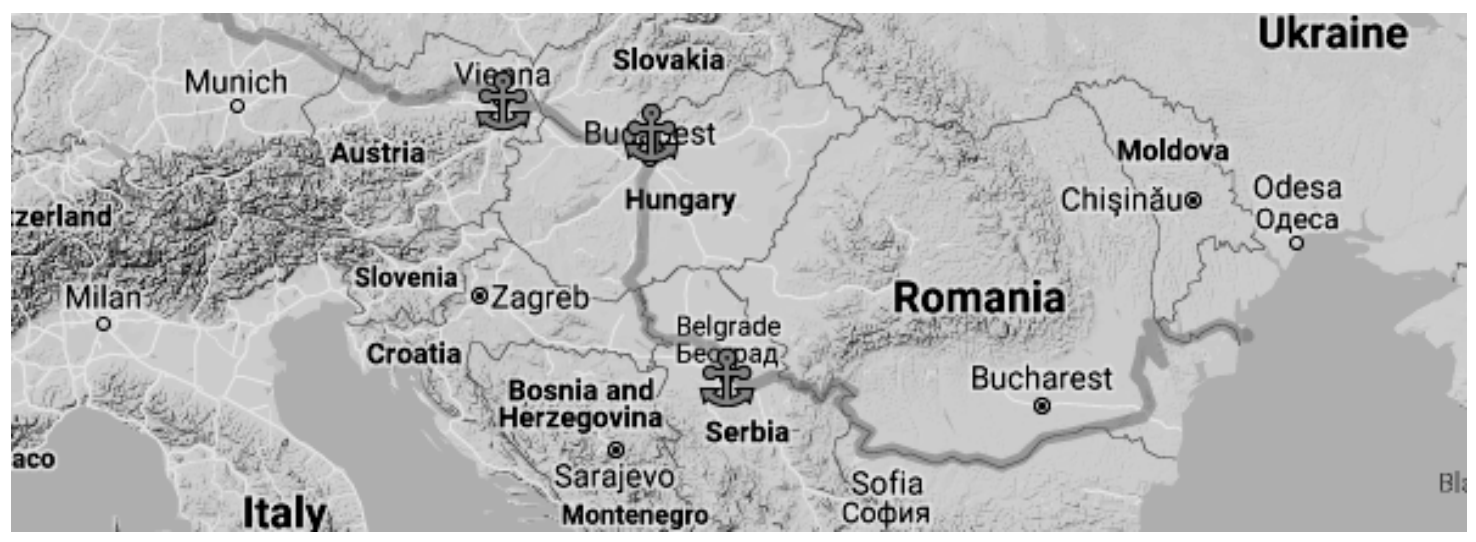

Source: own editing using Google My Maps

Vienna (1.8 million inhabitants) has based its tourist image on the title of the music capital of the world and is striving to appear as the capital of the Danube in terms of supply (Andrei Lianu, 2019). Austria has put great emphasis on creating favourable infrastructural conditions 
for cruise tourism. All modes of transport in Vienna are highly developed. Vienna has an airport (Flughafen Schwechat), which is $22 \mathrm{kms}$ from the city, and it is important for both passenger and cargo traffic. The port of Vienna plays an important logistical role in the region. After a significant expansion in 2013, the port area was increased by thirty-five thousand square meters (Dragin et al., 2017). The development of the Vienna port enables high-quality cruise traffic, which is a significant competitive advantage among the ports. The diverse tourist offer of the city is adjusted to the expectations of the primary target group (senior segment) (Jászberényi \& Miskolczi, 2020). The most popular section of Vienna is the city center (Innere Stadt), which is located between the Danube canal and the castle wall. St. Stephen's Cathedral, (Stephansdom) with its 97-meter high tower is a symbol of the city (Dumbrovská \& Fialová, 2014). The Ringstraße is a 3.5-4 km long, $57 \mathrm{~m}$ wide boulevard, closed at both ends by the Danube Canal. There are also attractions outside the city center, such as the Belvedere Palace (Schloss Belvedere), which is also a must-see attraction for Danube cruise tourists (Kádár, 2012).

Danube cruise tourism grants immense potential for Budapest (1.8 million inhabitants), as the capital city of Hungary is a regular departure/arrival point of trips due to its geographical location. In comparison to other cities along the Danube (e.g. Vienna which is a major competitor of Budapest), the major advantage of Budapest is the UNESCO World Heritage cityscape by the Danube, where cruise ships usually dock. There are 450,000-500,000 passenger arrivals per year in the city (Ásványi et al., 2018). Budapest is the central transport hub of Hungary, from where the main railway and road lines start in a radial direction, creating connections with the counties of Hungary and the major European cities. The international airport (Liszt Ferenc Nemzetközi Repülötér) is $15 \mathrm{~km}$ from the city center and serves air transport with two terminals (Jászberényi, 2019). Due to the sections of the national roads and Budapest-centricity, the capital is extremely congested, the huge transit traffic causes considerable difficulties. The large number of attractions of Budapest reinforces its role in Danube cruise tourism: the most popular sites include the Heroes' Square, the authentic Great Market Hall, the Opera House, the Fishermen's Bastion and the Buda Castle Palace, as well as many religious heritages (e.g. Matthias Church, Dohány Street Synagogue, St. Stephen's Basilica) (Dumbrovská \& Fialová, 2014). There are a handful of attractions in the suburbs of Budapest offered as optional tours, such as the artists' village of Szentendre (along the Danube), the Royal Palace and Gardens in Gödöllő and -rarely, only in some packagesthe equestrian park in Domony. 
The Serbian or Bulgarian-Romanian section of the Danube is an emerging region (Rácz, 2014). There are several travel packages on offer, which incorporates the cities of the region (e.g. Belgrade). Belgrade (1.3 million inhabitants) is located at the confluence of two major rivers, the Danube and the Sava, so it has several bridges, the two most significant are the Branko Bridge and the Gazela Bridge, which connect the Old Town with the New Town on the other side of the Sava (Rabotic, 2011). Motorways connect Belgrade to the north with Novi Sad and Budapest, to the south with Niš and to the west with Zagreb (Dragin - Jovičić Lukić, 2010). The city's airport (Nikola Tesla International Airport) is located $12 \mathrm{kms}$ from the downtown. Due to the urban growth and the intensified vehicle traffic, congestion is a serious problem for the city. To make the Serbian section of the Danube even more attractive for tourists, a new international port was built in Zimony. Belgrade's historic districts and buildings are the most prominent tourist attractions of the region. These include Skadarlija, Belgrade's Bohemian Quarter, the National Museum, Nikola Pašić Square, Terazije, Belgrade Fortress and the surrounding area (Dragin et al., 2017). There are 16 islands in the Danube and Sava in the interior of Belgrade, many of which are still undeveloped and have a great tourism potential.

\section{THEORETICAL BACKGROUND}

Accessibility usually refers to how a physical object (facility, location of a settlement, etc.) is accessed, i.e. the transport conditions for getting there (Van Wee et al., 2001). Often, only the transport and regional aspects (Vickerman et al., 1999; Litman, 2007) are in focus in the definition of accessibility. Undoubtedly, these factors substantially affect accessibility, but many other aspects are excluded from the interpretation suggesting only physical access. Farrington (2007) emphasizes the complexity of accessibility and points out that accessibility should be understood as a complex social phenomenon that is influenced by temporary and social factors.

Geurs \& van Wee (2004) also address the complexity of accessibility, which may be understood here as how the regional transport system allows individuals and goods to reach their destination (Fleischer, 2008; Tóth \& Dávid, 2010). Although the transport system seems to be dominant in this definition, the authors refer to the perspective of individuals and the time constraints that affect land use as well. Thus, the theory not only suggests a mobilitycentric approach, but also identifies four different accessibility components (Geurs \& van Wee, 2004): 
1) land use: the amount, quality and spatial distribution opportunities supplied at each destination, and the demand for the opportunities at origin locations;

2) transportation: the preferred mode for an individual to cover the distance between an origin and a destination using a specific transport mode (amount of time, effort);

3) temporal: the availability of opportunities at different times of the day, and the time available for individuals to participate in certain activities;

4) individual: the needs, abilities and opportunities of individuals.

In the present study, these four components of accessibility are studied in the context of Danube cruise tourism (Fig. 3).

Figure 3 Interpretation of the four components of accessibility - attraction-accessibility in the context of Danube cruise tourism

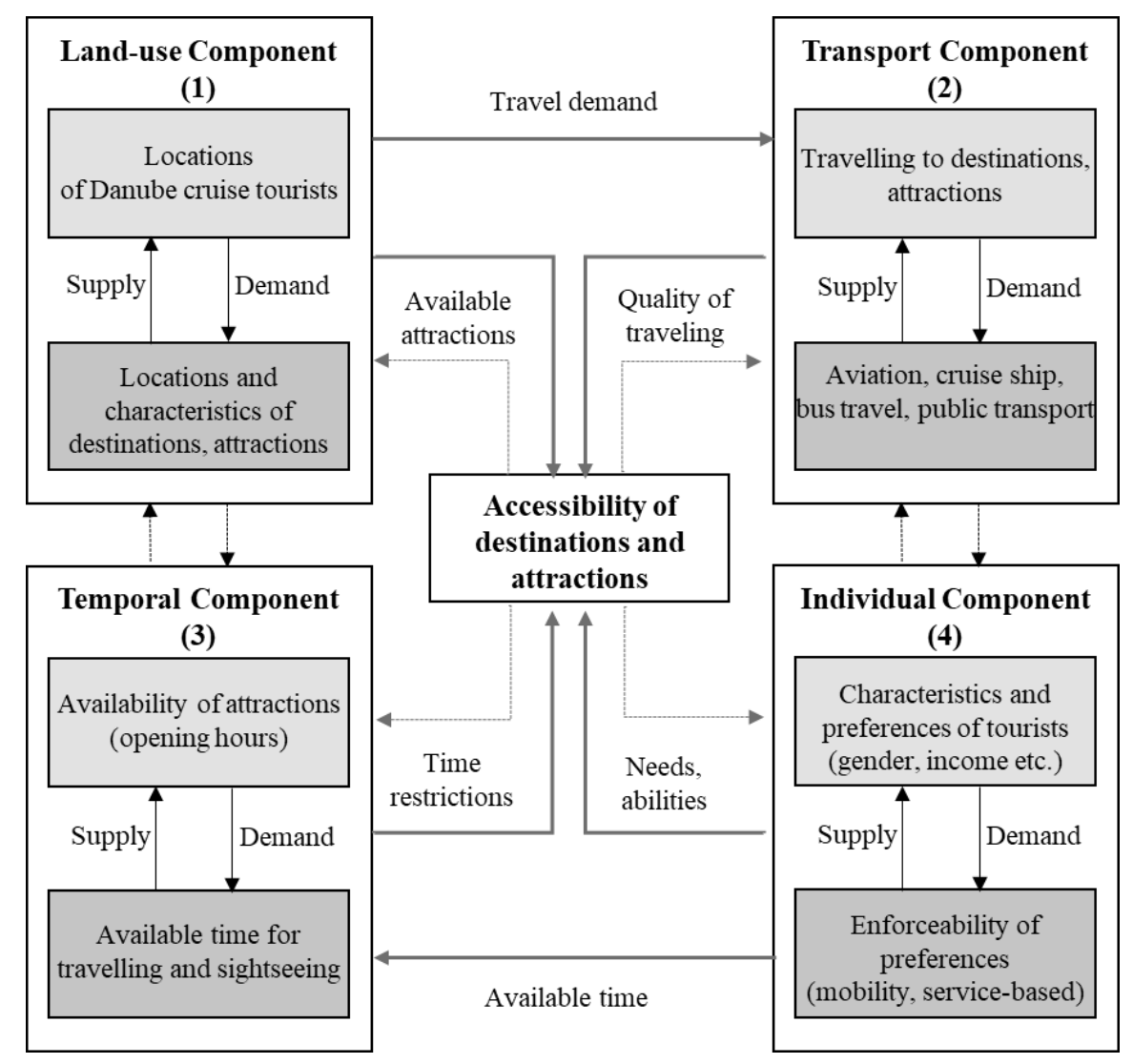

Source: Based on Geurs \& van Wee (2004), own editing

\section{DATA AND METHODS}

An exploratory research has been conducted to better understand the Danube cruise industry and especially attraction accessibility, without developing specific hypotheses. This research 
is based on flexible, semi-structured interviews, which is the best-known method of data collection in exploratory researches (Popper et al., 1997). Due to the time-consuming nature of interviews, the number of inquiries made in the research process is usually low (Malhotra \& Simon, 2017). Although the low number of sampling elements cannot be considered representative, it is useful to extend knowledge about the subject (Babbie, 2014).

In this case, 10 experts have been involved in the research personally: researchers, transport experts, port authority representatives, attraction managers, and tour operators. Three of the interviews (lasting 45-60 minutes) have fully or partially been taken online. The information provided by the interviewees has been processed anonymously.

The semi-structured discussions addressed four main topics:

1) questions about interviewees (job, interest and experience in Danube cruise tourism) and their general knowledge about cruise tourism,

2) transport for Danube cruise tourism (means of transport applied, transport logistics),

3) accessibility of attractions, identification of accessibility problems (affected attractions, accessibility, known accessibility problems),

4) suggestions for solving attraction accessibility issues (and recommendations about further research directions).

\section{RESULTS}

Interviewees were asked to identify problems of Danube river cruise tourism. In this chapter, some general issues are highlighted and interpreted along the four accessibility dimensions.

Based on the analysis of the expert interviews, five general issues related to river cruise tourism were identified. There is no doubt that the key challenge is the water level of the Danube (1). In October 2018, measurements by hydrologists at the General Directorate of [the Hungarian] Water Management (OVF) showed that the water broke a negative record of 71 years. Low water levels (below 1.6 meters) strongly influence the tourism experience, as tourists may be obliged to travel by bus and stay in hotels instead of cruise ships: "In periods of severe drought, passengers in Budapest or Vienna had to take a bus to Bratislava. This means that some programmes had to be cancelled due to low water levels" (attraction operator, Hungary).

Travelling by bus may influence temporal components as well, as time for visits to some attractions may be limited and transport of goods and personnel to ships may be rescheduled or even reorganised. Having in mind that cruise ships may be identified as (at least) four-star 
boutique hotels, rooms of similar category have to be arranged in case of drought. Evidently this might be challenging, especially in the high season of late summer or early autumn.

Packages, tours and excursions are usually planned, announced and sold years in advance, so unexpected changes to the accessibility of attractions (e.g. temporal closure due to reconstructions, new timetables) and to general accessibility (large scale road works, traffic restrictions, open festivals or runway races in public spaces, etc.) may affect the programme or its schedule (2). Changes may affect prices, too: "Some prices are not announced in advance. Last year, one of the attractions raised entrance fees by $20 \%$, and many museums are raising a lot, which means that we are no longer able to offer them in cruise packages" (tour operator, Serbia).

Overtourism and related mobility issues (3) are challenging in the top destinations. Furthermore, especially in small destinations, cruise tourists themselves may cause mobility problems: "Moving at least 160 people in a small town or attraction is complicated. For example, Dürnstein, with a total population of 800, is visited annually by 1 million cruise tourists. This mass of tourists is unable to be managed without disturbing local life" (tourism consultant, Austria).

Interviewees identified two further key problems, namely traffic congestions in cities (4) and parking problems (5), which are described below as transport components.

\section{The four components of accessibility}

\section{Land use component}

Elements of the land use component (1) are the quantity and spatial distribution of facilities offered by the destination (primarily tourist attractions frequented by cruise tourists), the spatial distribution of potential users (cruise tourists) and the relationship between these two factors (supply and demand) in the model. The attractions affected by cruise tourism are primarily limited to heritage tourist attractions and high-end restaurants. ("Tourists often spend their life-saving money to visit these historic treasures and to experience this luxurious service palette" - manager, tourist information office, Hungary.)

In this case, the spatial location of tourists includes the distance between the place of residence and the visited destination, and the distance between the cruise ship and urban attractions. As mentioned above, most of the cruise tourism attractions are in the central area of destinations (e.g. Vienna - Schönbrunn Palace, Budapest - Parliament, Belgrade - The Church of Saint Sava, etc.) and its close vicinity (e.g. Budapest - Royal Palace of Gödöllö). 
Spatial distribution of facilities includes the key infrastructural features of the wider and immediate surroundings of the attractions (e.g. the capacity of parking spaces for buses) and the design of the interior of the attractions (e.g. accessibility for disabled people).

The main users of cruise tourism are Western European (German, Dutch, Swedish, English, Italian) and overseas (North American, Panamanian, Peruvian, Australian, Chinese) people. Due the long distances from these countries to the destination, travel needs of cruise tourists are complex, which affects the range of transport components.

\section{Transport components}

Transport components (2) refer to the transport processes between the starting point and the destination, including the means of transport available for passengers (van Wee et al., 2001).

Although some river cruise tourists (mainly from Germany) use individual or rarely other modes of transport (car or rail), airplane can be considered the main mode of transport between the place of residence (see main countries of origin above) and the starting/end points of the river cruise, usually due to the large distances. From the airport, shuttle services (usually by car or minibus) are provided, mainly as part of the travel package. Taxi and public transport are used by some tourists individually.

Within the destination area, to reach attractions, companies hire or use mostly buses, which are selected under strict quality standards. ("Buses are very carefully selected, and in the case of several program organizers, the maximum age of a vehicle must be 5 years", product manager, cruise company, Switzerland.) For short distances, micromobility vehicles (traditional or e-bikes, segway, etc.) and mainly walking is applied. Active mobility is encouraged on thematic cruises and for excursions (e.g. bike, hiking and canoe tours). Travelling on public transport was unusual for a long time but nowadays it is becoming efficient for small groups, especially in case of attractions in the city centres, where buses and even cars may face large traffic and entry or parking restrictions.

In cities, the main mobility problem is traffic congestion (2): "Traffic jams are common even in off-peak hours. As a result, ships are often unable to depart on time, thus the entire programme may be delayed." (port operations manager, Hungary). Another common issue is the lack of proper parking spaces close to top attractions (3): “There are no parking places near many attractions of Budapest, tourists can only get on and off. We are in a relatively lucky position, there is a gas station and a mall nearby and we direct the groups there. Some tourists are not happy about this (short) distance, but they have to accept the situation" (attraction operator, Hungary). By making difficult or longer the journeys to attraction areas, 
increasing the time to reach attractions from relatively distant parking places (or bus stops), these transport components may strongly affect the tourist experience.

In the special case of Budapest, parking problems are not limited to attractions but also to the port, which is located in the city centre, along a busy north-east bypass. In high season, several ships are docked here and at least 3 buses per ship are needed to provide transfer to attractions. Dedicated parking spaces are insufficient there to meet these needs at the same time. In the case of the other two ports, docking is less of a problem. A specially designed port is available in Vienna: each berth has a separate lockable garbage collector; vessels can be connected to the drinking water network and even to the sewage network, so that already treated wastewater generated on board can be discharged into the land-based sewerage system. The Belgrade port is not right next to the Danube, but on the banks of the Sava. No such infrastructure is built in the Sava estuary, but it has been resolved to place office buildings and shops on huge floating bodies.

\section{Temporal components}

The temporal component (3) refers to the time availability of facilities from different aspects: regular availability (e.g. opening hours of attractions on a certain day, weekly timetable) and temporal availability (e.g. schedule of temporary exhibitions, seasonal opening of attractions). In this analysis, the extended interpretation of temporal components (Fleischer, 2008) is applied. Time constraints (e.g. travel time, seasonality, available leisure time) and the availability of means of transport and roads (e.g. departure of flights, seasonal schedule, etc.) are labelled as temporal component here.

The total duration of a river cruise usually varies from 7 to 20 days in the analysed region. As tours are typically scheduled to a morning or afternoon session (e.g. from $2 \mathrm{pm}$ to $6 \mathrm{pm}$ ), travel time between the port and the attractions is usually not more than 45 minutes. For example, the above-mentioned Royal Palace of Gödöllö (Hungary) (35 km from Budapest port, 40-45 minutes) and Schönbrunn Palace (Austria) (8 km from Vienna port, 20-25 minutes) both meet this criterion. Only a few operators or programme organisers offer special tours to attractions beyond this time limit, e.g. day excursions.

Due to the limited time available for visiting attractions, opening hours must be compatible with the timetable of packages. It is worth mentioning here that Budapest is typically the starting or ending point of trips, where pre or post extensions are offered with cruise packages. This extends the available time for visiting attractions in and near the city, with tour guides or individually. Vienna and Belgrade appear only as intermediate destinations in the 
Miskolczi, M., Jászberényi, M., Munkácsy, A., Nagy, D.

packages, so adhering to a tight schedule is a higher difficulty. Taking into consideration tight schedules, travel time predictability is a critical factor: "Groups and tours need to be very precise. The plan may often fail due to ten minutes delay because of the very tight schedule. Tourists have to finish sightseeing usually between 2-6 in the afternoon" (managing director, destination management company, Austria), which is the busy afternoon peak in urban traffic. The same applies for the morning peak when most groups depart from the port in the city centre.

\section{Individual components}

The individual components (4) include the personal aspects of access to transport, as well as the needs and abilities of individuals (tourists). These include:

1) demographic characteristics (age, financial means: willing to pay for attractions),

2) psychographic characteristics (travel motivation, leisure time, mobility patterns), and individual abilities such as health and mobility (Geurs \& van Wee, 2004).

3) Fleischer (2008) extended the role of the individual aspects not only to transport related aspects but also to accessibility of all kinds of services (e.g. if the tourist is physically or mentally able to perceive and understand the attraction).

Currently, the demographic characteristics of cruise tourists are the most decisive human components of attraction accessibility: "The composition of cruise tourists is significantly different from any other tourism product. We meet a lot of elderly, above 80, with walkers and wheelchairs and they need a lot more care and accessible attractions" (attraction operator, Austria).

Due to the tourists' health status, they are usually transported by bus (or other motorised vehicles) to attractions. On walking tours, tourists are often grouped in line with their intentions to walk or their mobility abilities. Thus, tourists with reduced mobility might form a special group, whose walking distances are minimized and the range of visited attractions is limited to accessible sites. They can visit fewer attractions but can get a deeper insight of each of them. In spite of advances toward full accessibility of attractions, the lack of elevators and ramps still makes it difficult for people with reduced mobility to visit some places (including public spaces).

In terms of psychographic features, a new trend has been emerging, namely that river cruise tourists prefer real authentic experiences. They tend to choose more complex but more promising and odd routes, which allow them to get acquainted with local experience, such as rural culture, country landscape, family life, etc. On the one hand, this led to new products, 
such as visits to traditional workshops, real family homes, small wine cellars. On the other hand, in terms of attraction accessibility, non-authentic itineraries are avoided to somehow get acquainted with local life (e.g. buses cross villages through country roads instead of motorways).

According to some experts, the appearance of multigenerational tourist groups is becoming more widespread in the near future, which may influence the selection of attractions and may raise new accessibility challenges: "In the next few years, we can expect groups where grandchildren and grandparents travel together and this trend will require notable service and ship conversion..." (port operations manager, Serbia).

\section{SUGGESTIONS BY THE RESPONDENTS}

As part of the interviews, respondents were asked to suggest solutions (see below) to the key challenges of river cruising on the Danube (described above), which are linked to more than one accessibility component. Among the suggestions, only proposals that have been considered feasible in light of the specifics of the industry are highlighted.Accessibility components affected by a certain proposal are also emphasized (Table 1).

Table 1 General problems and potential solutions about accessibility in Danube cruise tourism

\begin{tabular}{|c|c|c|c|c|c|}
\hline \multirow{2}{*}{$\begin{array}{l}\text { Identified } \\
\text { problem }\end{array}$} & \multirow[t]{2}{*}{ Suggestion } & \multicolumn{4}{|c|}{ Components of accessibility } \\
\hline & & $\begin{array}{l}\text { Land use } \\
\text { component }\end{array}$ & $\begin{array}{l}\text { Transport } \\
\text { component }\end{array}$ & $\begin{array}{l}\text { Temporal } \\
\text { component }\end{array}$ & $\begin{array}{l}\text { Individual } \\
\text { component }\end{array}$ \\
\hline \multirow{2}{*}{$\begin{array}{l}\text { Navigability } \\
\text { issues }\end{array}$} & $\begin{array}{l}\text { monitoring of water } \\
\text { level }\end{array}$ & & $\mathbf{X}$ & $\mathbf{X}$ & \\
\hline & $\begin{array}{l}\text { (preparations for) } \\
\text { contracting alternative } \\
\text { services }\end{array}$ & & $\mathbf{X}$ & & \\
\hline \multirow{2}{*}{$\begin{array}{l}\text { Traffic } \\
\text { congestions in } \\
\text { cities }\end{array}$} & $\begin{array}{l}\text { integrated information } \\
\text { interface (application) }\end{array}$ & $\mathbf{X}$ & $\mathbf{X}$ & $\mathbf{X}$ & \\
\hline & $\begin{array}{l}\text { development of urban } \\
\text { traffic management } \\
\text { system }\end{array}$ & & $\mathbf{X}$ & $\mathbf{X}$ & \\
\hline $\begin{array}{l}\text { Shortage of } \\
\text { parking places }\end{array}$ & $\begin{array}{l}\text { designation of dedicated } \\
\text { areas }\end{array}$ & $\mathbf{X}$ & $\mathbf{X}$ & & \\
\hline \multirow{2}{*}{ Overtourism } & $\begin{array}{l}\text { extending the range of } \\
\text { attractions to visit }\end{array}$ & & & & $\mathbf{X}$ \\
\hline & reservation system & $(\mathrm{X})$ & & $\mathbf{X}$ & \\
\hline
\end{tabular}

Source: own editing 
Low water levels may essentially increase travel time and/or even prevent tourists from using the main element of the tourism experience, namely the cruise ship as a place for accommodation, food, drink, entertainment, etc. and a mode of transport. In order to minimize the negative impacts, it is necessary to identify in advance and reserve transport and accommodation alternatives of the same quality.

To reduce the effects of urban traffic congestions, experts suggested solutions far beyond the cruising industry, namely developing (road) route planners or extending existing route planning applications with tourism and logistics type options (such as best routes for buses, routes including stops or parking places for buses, etc.). This is linked to land-use, transport and temporal components, as it would provide service providers with up-to-date or real-time information (availability, capacity, current occupancy, etc.) about traffic conditions (diversions, barriers, etc.) and specific infrastructure (e.g. parking lots for buses, restrictions for certain types of vehicles). On city level, this could work as part of (or be compatible with) an urban traffic management system that takes into consideration the already mentioned tourism and city logistics aspects. One of the key solutions could be some improvements in transport and land-use components, i.e. dedicated parking spaces could be designated for buses and other vehicles (trucks, vehicles of the crew, etc.) not far from the port, but not necessarily in the city centre. Shortcomings of stops close to attractions in central areas could hardly be overcome due to the lack of space. Experts expect improvements of the infrastructure and better coordination with other services (especially hop-on/hop-off sightseeing buses and public transport services) that use these stops. It is worth noting that according to some experts- providing high-quality local public transport can solve much of this problem. The use of a variety of alternative means of transport (especially walking, biking, pedelecs, segway, etc.) can also help to reduce the negative effects of urban road traffic, which would result in a more convenient way to reach attractions (especially for small groups and tourists of younger age).

Overtourism-related mobility issues, especially delays due to congested public spaces and slow entry to attractions, might be mitigated by reservation systems. Although this is becoming common in institutions (especially museums), entry to attraction areas (parks, historical city centres, main squares, etc.) is not controlled or managed. The reservation system facilitates transport for tourist purposes and reduces the congestion of infrastructure. Following the same principle, the parking system of the Schönbrunn Palace in Vienna was redesigned. 
Respondents recommend expanding the range of attractions to be visited. In a time when people are looking for authentic experiences, less visited and therefore less crowded attractions can be alternatives to popular sites (waiting for entry, crowding in the attraction area, etc.) and the mass presence of other tourists may be unattractive. Visits to these attractions can be organised in smaller groups, on foot, by bicycle or by public transport (perhaps by car or minibus for longer distances), avoiding traffic congestion and parking issues.

A general suggestion by respondents is the extension of user groups (targeting people of younger ages) and therefore the reconsideration of the essentials of river cruising: young couples, groups of young friends, families with young children, etc. would require more affordable travel packages, shorter stays and new types of attractions, including the use of active travel modes to a larger extent.

\section{SUMMARY}

In this article, some accessibility issues of tourist attractions have been analyzed in the context of Danube river cruise tourism. The four accessibility components (land-use, transport, temporal and individual) have been adapted from the model by Geurs \& van Wee (2004), taking into account remarks by Fleischer (2008). As a general conclusion, the complexity of accessibility in this context -namely that besides transport components many other influencing factors shape the accessibility of attractions- has been confirmed by the results of this qualitative research based on expert and stakeholder interviews.

Five general problems have arisen: water level of the Danube, reliability of pre-arranged services, overtourism, and -especially in urban areas- traffic congestion and parking issues for buses. Solutions (identified in line with accessibility components) have also been suggested by interviewees.

The main conclusion of the research is that key challenges of river cruise tourism (especially but not only in the context of the three major ports) should be mitigated by actors outside this industry: bodies responsible for water(way) management, urban mobility management and urban policy. However, the tourism industry also has its role in improving conditions of attraction accessibility (by more flexibility in time, better coordination and communication between operators, etc.) having in mind sustainability and liveability issues especially in destination areas. 
Among the limitations of the research, it should be mentioned that the analysis was completed before the outbreak of the current pandemic, which led to a recession and a significant reorganization of the whole tourism industry. In the post-epidemic period, accessibility problems are likely to remain valid, however, product development proposals (e.g., targeting certain consumer groups) may need to be reconsidered.Having this in mind, next steps of this research would reveal further aspects of accessibility by extending the research sample (urban experts, crew members, public transport operators, etc.)which facilitates the updating and comparability of our results. As the demand for river cruise tourism has not yet been analysed in detail (besides market research), detecting the expectations, beliefs and needs of target groups, as well as characteristics of actual passengers (e.g. understanding factors that influence their decisions) would be a relevant contribution to the literature.

\section{REFERENCES}

Andrei, M. T., \& Lianu, C. (2019). Branding and tourism development perspectives for small Romanian cities along the Danube. Annals of Spiru Haret University, Journalism Studies, 20(2), 338-357.

Avalon Waterways.com (2020). Danube river. Retrieved from: https://www.avalonwaterways.com/River-Cruises/Danube-River/

Babbie, E. R. (2014). The practice of social research. Cengage, England.

Brida, J. G., \& Zapata, S. (2010). Cruises Tourism: Economic, Socio-cultural and Environmental Impacts. International Journal of Leisure and Tourism marketing. Vol. 1, no. 3, 205-226.

Crystalcruises.com (2020). Crystal Cruises on the Danube. Retrieved from: https://www.crystalcruises.com/

Danube International Programme (2019). Cruise Tourism in the Danube Region. Final Report [PDF]; Ministry of Tourism of the Republic of Bulgaria, Sofia, Bulgaria. Retrieved from: https://danube-region.eu/wp-content/uploads/2020/01/Cruise-Tourism-in-theDR Report ENG.pdf

Dragin, A. S., Jovičić, D., \& Lukić, T. (2010). Cruising along the river Danube: Contemporary tourism trend in Serbia. Geographica Pannonica, 14(3), 98-108.

Dragin, A., Dragin, V., Košić, K., Demirović, D., \& Ivkov-Džigurski, A. (2017). Tourists motives and residents' attitude towards cruisers. South. East. Eur. 4, 133-144.

Dumbrovská, V., \& Fialová, D. (2014). Tourist intensity in capital cities in Central Europe: comparative analysis of tourism in Prague, Vienna and Budapest. Czech Journal of Tourism, 3(1), 5-26.

Erdeji, I., \& Dragin, A. (2017). Is cruising along European rivers primarily intended for seniors and workers from Eastern Europe? Geographica Pannonica, 21(2), 115-123.

Erfurt-Cooper, P. (2009). European waterways as a source of leisure and recreation. River Tour., 3, 95-116.

Farrington, J. H. (2007). The new narrative of accessibility: its potential contribution to discourses in (transport) geography. Journal of Transport Geography, 15(5), 319-330. 
Fleischer, T. (2008). Az elérhetőségről: azelérhetőségfogalma. Közúti és mélyépitésiszemle, 58(1-2), 1-6.

Geurs, K. T., \& van Wee, B. (2004). Accessibility evaluation of land use and transport strategies: review and research directions. Journal of Transport Geography, 12(2), 127140.

Israeli, A. A. (2002). A preliminary investigation of the importance of site accessibility factors for disabled tourists. Journal of Travel Research, 41(1), 101-104.

Israeli, Y., \& Mansfeld, Y. (2003). Transportation accessibility to and within tourist attractions in the old city of Jerusalem. Tourism Geographies, 5(4), 461-481.

Jászberényi, M., \& Ásványi, K. (2015). The image of Budapest as the best river cruise port city. Budapest: Corvinus University of Budapest, Economic Geography and Future Studies Department, pp. 140-148.

Jászberényi, M. (2018). A turizmus a belvizi és tengeri hajózásban. In Jászberényi, M., \& Munkácsy, A. (Eds.), Közlekedés, mobilitás, turizmus. Budapest: Akadémiai Kiadó.

Jászberényi, M. (2019). Vizi turizmus és közlekedés: termékek, trendek, regionalitás. Budapest: Akadémiai Kiadó.

Jászberényi, M., \& Miskolczi, M. (2020). Danube Cruise Tourism as a Niche Product - An Overview of the Current Supply and Potential. Sustainability, 12(11), 4598.

Johnson, D. (2002). Environmentally Sustainable Cruise tourism: A Reality Check. Marine Policy, 26, pp. 261-270.

Kádár, B. (2012). Spatial patterns of urban tourism in Vienna, Prague and Budapest. Metropolitan regions in Europe, 7(1), 277-312.

Klein, R. A. (2011). Responsible Cruise Tourism Issues of Cruise Tourism and Sustainability Journal of Hospitality and Tourism Management, 18(1), 107-118.

Litman, T. (2008). Evaluating accessibility for transportation planning. Victoria Transport Policy Institute, Victoria, Canada.

Malhotra, N. K., \& Simon, J. (2017). Marketingkutatás. Budapest: Akadémiai Kiadó.

Popper, K. R., Petri, G., \& Szegedi, P. (1997). A tudományoskutatáslogikája. Budapest: Európa Kiadó.

Rabotic, B. (2011). American tourists' perceptions of tourist guides in Belgrade. UTMS Journal of Economics, 2(2), 151-161.

Rácz, Sz. (2014). New integration period?: Changing tendencies of the urban network in South-East Europe. DetEurope: Central European Journal of Tourism and Regional Development, 6(2), 46-63.

Santos, M., Radicchi, E., \& Zagnoli, P. (2019). Port's Role as a Determinant of Cruise Destination Socio-Economic Sustainability. Sustainability, 11(17), 4542.

Tauck.com (2020). Danube river cruising. Retrieved from: http://www.tauck.com/rivercruises/european-river-cruises/danube-river-cruising.aspx

Tóth, G., \& Dávid, L. (2010). Tourism and accessibility: An integrated approach. Applied Geography, 30(4), 666-677.

Turtureanu, A. G. (2015). The Current State of Tourism Traffic along the Danube on the Romanian Territory. Acta Universitatis Danubius. CEconomica, 11(5), 141-148.

Uniworld.com (2020). River cruise collection on the Danube. Retrieved from: Collection https://www.uniworld.com/eu/

Van Wee, B., Hagoort, M., \& Annema, J. A. (2001). Accessibility measures with competition. Journal of Transport Geography, 9, 199-208.

Vickerman, R., Spiekermann, K., \& Wegener, M. (1999). Accessibility and economic development in Europe. Regional studies, 33(1), 1-15.

Vikingrivercruises.co.uk (2020). Danube river cruises. Retrieved from: https://www.vikingrivercruises.co.uk/ 
Miskolczi, M., Jászberényi, M., Munkácsy, A., Nagy, D.

Vuksanović, N., Pivac, T., \& Dragin, A. (2013). Contemporary trends in nautical tourism on the example of European river cruising companies. Res. Rev. Dep. Geogr. Tour. Hotel Manag., 42, 122-138.

Xu, S., Barbieri, C., \& Seekamp, E. (2020). Social Capital along Wine Trails: Spilling the Wine to Residents? Sustainability, 12(4), 1592.

Yau, M. K. S., McKercher, B., \& Packer, T. L. (2004). Traveling with a disability: More than an access issue. Annals of tourism research, 31(4), 946-960. 